\title{
Experiences gained and major challenges for the remediation of Wismut's Culmitzsch tailings pond
}

\author{
U. Barnekow Department of Mine Remediation/Geotechnics, Wismut GmbH, Germany \\ J. Müller Tailings Remediation Project, Remediation Unit Ronneburg, Wismut GmbH, Germany \\ T. Metschies Department of Mine Remediation/Geotechnics, Wismut GmbH, Germany \\ M. Paul Division Engineering and Radiation Protection, Wismut GmbH, Germany
}

\begin{abstract}
From 1960 to 1990 the former Soviet-German Wismut company milled uranium ore and processed a total of about 110,000 t of uranium at the Seelingstaedt mill in Thuringia, Germany. As part of its mine closure program the state-owned Wismut $\mathrm{GmbH}$ is remediating the Culmitzsch Uranium tailings pond covering $2.4 \mathrm{~km}^{2}$ (vol. $\left.85 \mathrm{M} \mathrm{m}^{3}\right)$. To date, the Culmitzsch tailings pond has been partly interim covered and re-contoured. Final covering, landscaping and vegetation including hydraulics constructions are foreseen to be completed by 2022. The paper presents experiences gained and conclusions from the management of contaminated waters within the overall water management of the site. In addition the paper presents on-site-monitoring results of ongoing tailings consolidation influencing the overall water management of the site. Experiences from water management and the major challenges for granting the future remediation progress for the entire site are discussed with regard to the technical conditions and legal restrictions for water release to the receiving streams and concepts for surface cover design. Finally the paper provides an outlook to the long term after remediation.
\end{abstract}

\section{Introduction}

From 1960 to 1990 the former Soviet-German Wismut company milled uranium ore and processed a total of about 110,000 t of uranium at the Seelingstaedt mill in Thuringia, Germany. As part of its mine closure program the state-owned Wismut $\mathrm{GmbH}$ is remediating the Culmitzsch Uranium tailings pond (TP) covering $2.4 \mathrm{~km}^{2}$ (vol. $85 \mathrm{M} \mathrm{m}^{3}$ ). The Culmitzsch TP was erected in the former uranium open pit Culmitzsch. It consists of two partial ponds $A$ and $B$ surrounded by rock-fill dams made with waste rock and a separating dam with a vertical sealing in the centre. From 1967 to 1990 tailings from acid leaching of uranium ore were disposed into partial pond $A\left(1.6 \mathrm{~km}^{2} ; 62 \mathrm{M} \mathrm{m}^{3}\right)$ and from soda-alkaline leaching into partial pond $B$ $\left(0.84 \mathrm{~km}^{2} ; 23 \mathrm{M} \mathrm{m}^{3}\right)$ resulting in $55 \mathrm{~m}$ to $72 \mathrm{~m}$ thick tailings layers. Several villages are located in the immediate vicinity of the TP. Contaminant leakage from the tailings enters the surrounding aquifers and the receiving streams. In situ dry remediation started in 1991. While re-contouring of the Culmitzsch TP has started in 2007 there are to date $\sim 10$ ha of fine tailings surfaces of pond $A$ uncovered. Dam reshaping and re-contouring of tailings beaches is completed on pond $B$ while ongoing on pond $A$. The fine tailings zone of pond $B$ is currently being re-contoured. Final covering, landscaping and vegetation including hydraulics constructions and road construction are foreseen to be completed by $\sim 2022$. The paper presents experiences gained and conclusions from the management of contaminated waters within the overall water management of the site. In addition the paper presents on-site-monitoring results of ongoing tailings consolidation influencing the overall water management of the site.

\section{Site characterisation}

The water management of the Culmitzsch TP is part of the overall water management of all mining sites of Wismut at Seelingstaedt including also the Truenzig TP $\left(1.2 \mathrm{~km}^{2}, 19 \mathrm{M} \mathrm{m}^{3}\right)$ and the former Uranium mill and 
processing plant Seelingstaedt. The locations of the TPs and of the Seelingstaedt mill and the respective regional catchment areas are presented with Figure 1.

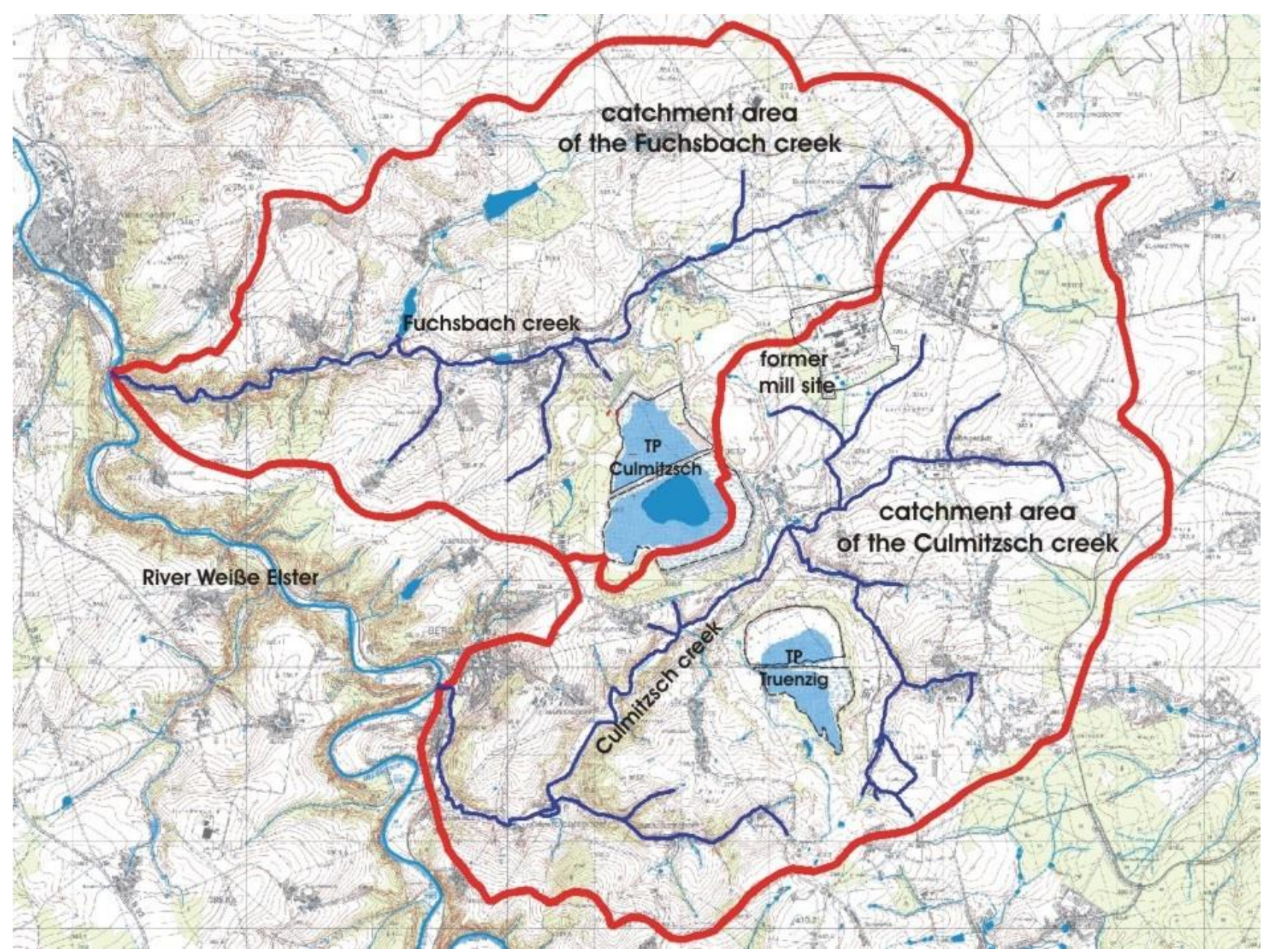

\section{Figure 1 Wismut's sites nearby Seelingstaedt within the regional catchment areas}

The Truenzig TP and the southern smaller part of the Culmitzsch TP are located in the hydrological catchment area of the Culmitzsch/Poeltschbach Creek, called in the following just Culmitzsch Creek. The Culmitzsch Creek is classified as a river of second order with some feeder rivers like the Finkenbach Creek. The Culmitzsch Creek flows into the river Weisse Elster. The respective catchment area is $40.8 \mathrm{~km}^{2}$ including the area of the mining sites. The entire length of this creek is about $11 \mathrm{~km}$. The major part of the Culmitzsch TP is located within the regional catchment area of the Fuchsbach Creek. The Fuchsbach Creek is a river of second order with some feeder rivers. The respective catchment area of the Fuchsbach Creek is $33.8 \mathrm{~km}^{2}$ including the mining sites. The entire length of this creek is approximately $10.7 \mathrm{~km}$. Both the Culmitzsch Creek and the Fuchsbach Creek are flowing into the river Weisse Elster (Figure 1).

The Wismut sites nearby Seelingstaedt are located in Eastern Thuringia in the transitional climate zone of the temperate latitudes. The average annual temperature is $8.1^{\circ} \mathrm{C}$. The measured average annual rainfall at the reference weather station nearby the next major city Gera is about $715 \mathrm{~mm}$. Rainfall generally occurs throughout the year. Frost period usually lasts from December until February.

Figure 2 shows the Culmitzsch TP in 1991 (view from NW to SE). Figure 3 presents a NW-SE oriented geological cross-section (from left to right: Culmitzsch partial pond B and $A$ and Truenzig partial pond $A$ and B). The cross section parallels the main groundwater flow direction. The Culmitzsch TP is located northwest of the Truenzig TP (left side on Figure 3). Figure 3 shows the tailings embankments, internal waste rock dumps and the major geological layers. Due to open pit mining the overburden materials were relocated from the open pits onto the waste rock dumps in the surrounding and inside the open pits. The Culmitzsch 
uranium open pit was mined out from 1957 till 1967. Two layers of grey mudstone or siltstone respectively were mined as uranium rich strata. The ore layers were part of nearly horizontally bedded sedimentary rock layers of Permian age situated in a half-graben. The up to $70 \mathrm{~m}$ thick Permian rocks are underlain by Ordovician shales folded in the Variscian orogenesis. The Permian sedimentary rocks consist from bottom to top of a base conglomerate, mudstone, siltstone and sandstone layers (in particular the main aquifer layer 'Culmitzsch sandstone') overlain by a thin layer of weathered dolomite residues, a weathered mudstone and a sandstone layer of lower triassic age. Due to open pit mining overburden materials were relocated onto the large waste rock dumps in the surrounding of and inside the open pit it. Three rock-fill dams were erected from 1963 till 1966 enclosing two partial ponds A (Figure 2 background)) and B (Figure 2 foreground). The dams include the north dam, the south and southeast dam and the separating dam. The separating dam has a vertical sealing wall in the dam centre. Tailings were disposed into Truenzig TP from 1960 till 1967 (Figure 3) and into the Culmitzsch TP from 1967 till 1990.

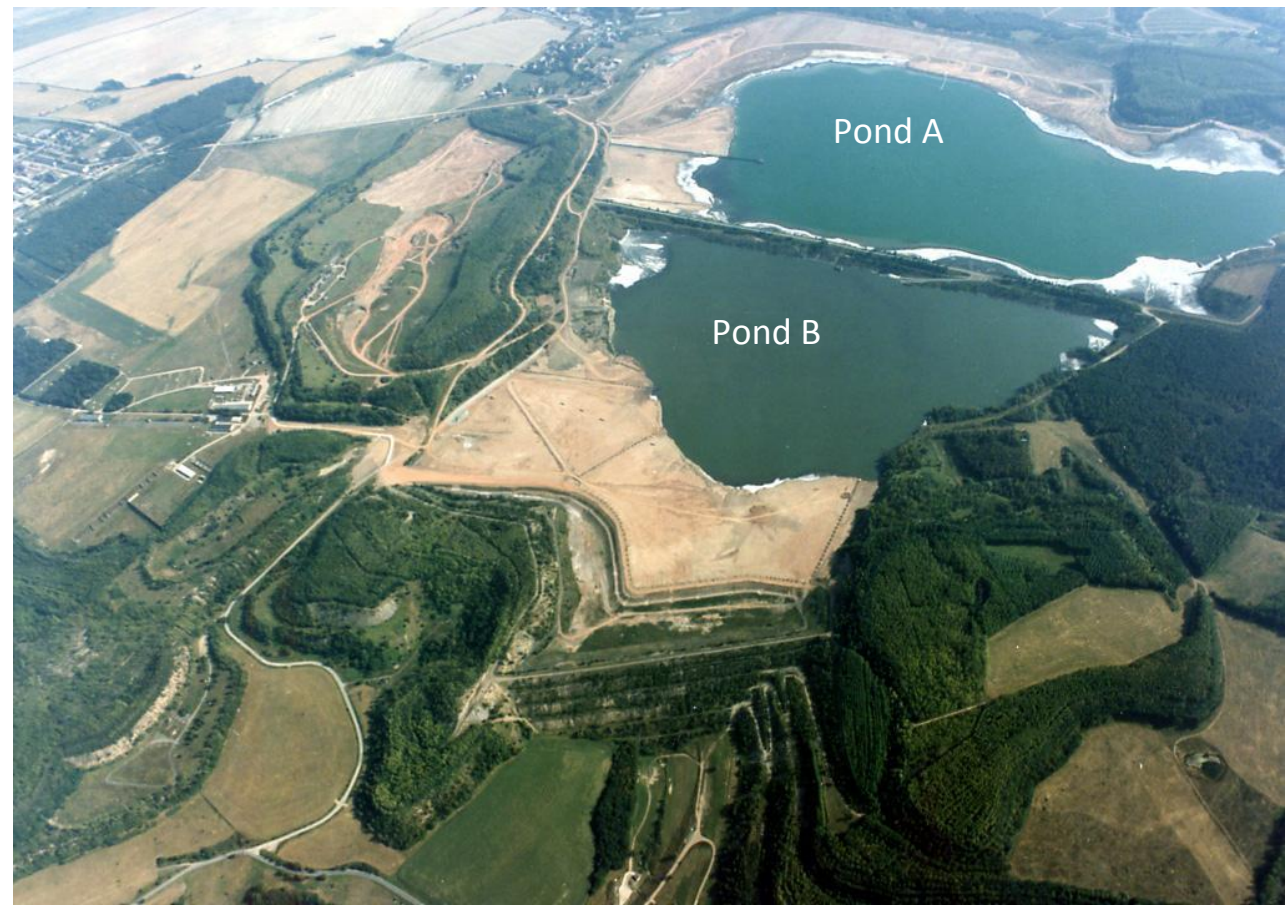

Figure 2 Culmitzsch TP A and B in 1991 (aerial view from NW to SE)
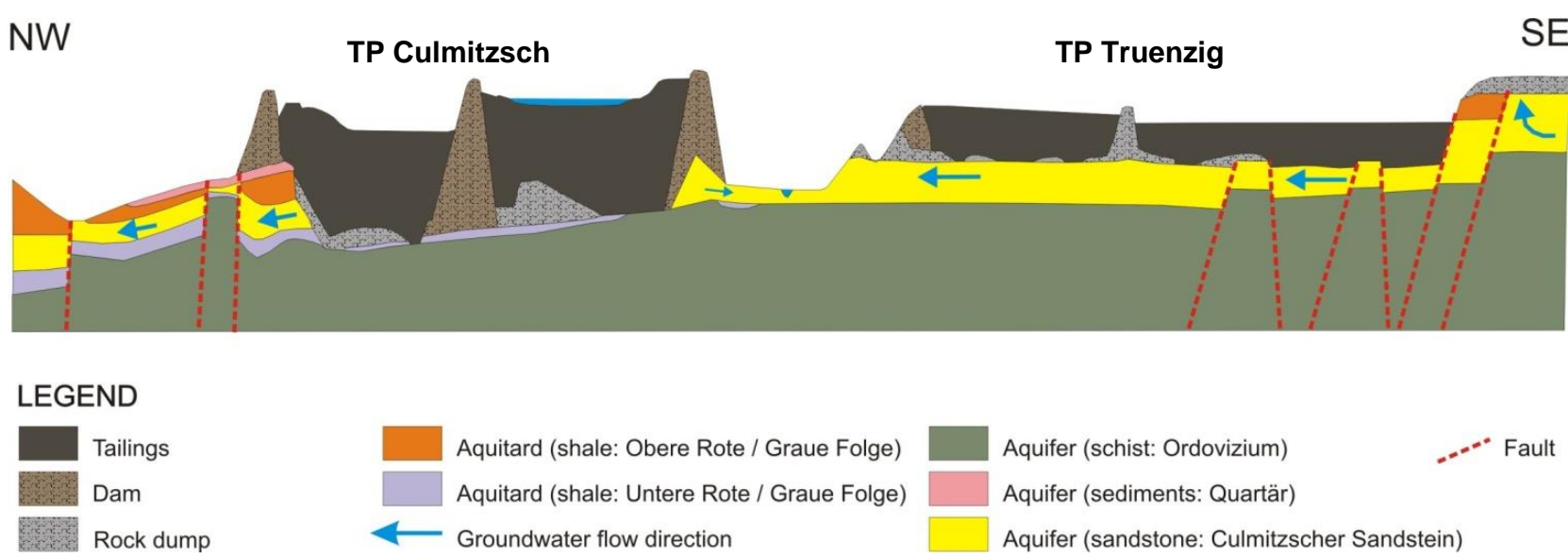

Figure 3 Geological cross section NW-SE across the TP

At both Culmitzsch and Truenzig TP Uranium mill tailings from acid leaching were disposed into the partial pond $A$ after being neutralised while tailings from soda-alkaline leaching were disposed into the partial pond B. According to the historic discharge regime sandy tailings beaches settled near the discharge spots 
while fine tailings settled more distant below water table. For both the Truenzig and the Culmitzsch TP the hydraulic regime in the permeable surrounding or underlying geological layers, in particular in the main aquifer layer Culmitzsch sandstone, is closely connected with the hydraulic conditions in the permeable sandy tailings. Because no base sealing was constructed before the start of tailings disposal pore water is released by percolation through the TP into the aquifer below and adjacent to the TP. This process has been continuing for the operational period resulting in an extensive contamination plume in the groundwater downstream of the TP. Even with the implementation of a cover the impacted area will act as contaminant source over a long period of time making long-term water management measures necessary at the TP and in its vicinity.

Table 1 shows the concentrations of relevant species within the tailings pore water with respect to the tailings beaches, transition zones and fine tailings zones for the two partial ponds A and B of Culmitzsch TP. Among others these parameters are of major concern for the environmental impacts downstream of the TPs.

Table 1 Concentrations of selected species tailings pore water measured in groundwater monitoring wells for Culmitzsch pond A and B (tailings beaches and in fine tailings zone (2007-2012)

\begin{tabular}{|c|c|c|c|c|c|c|c|}
\hline & pH & $\begin{array}{c}\mathrm{U} \\
\mathrm{mg} / \mathrm{I}\end{array}$ & $\begin{array}{l}\text { Hardness } \\
{ }^{\circ} \mathrm{dH}\end{array}$ & $\begin{array}{l}\mathrm{SO}_{4} \\
\mathrm{mg} / \mathrm{l}\end{array}$ & $\begin{array}{c}\mathrm{Fe} \\
\mathrm{mg} / \mathrm{l}\end{array}$ & $\begin{array}{c}\mathrm{Ni} \\
\mathrm{mg} / \mathrm{I}\end{array}$ & $\begin{array}{c}\mathrm{Zn} \\
\mathrm{mg} / \mathrm{l}\end{array}$ \\
\hline & \multicolumn{7}{|c|}{ Culmitzsch A - Tailings Beaches (11 wells) } \\
\hline Min. & 6.1 & 0.03 & 260 & 8,100 & $<0.02$ & 0.2 & $<0.03$ \\
\hline Max. & 8.6 & 6.5 & 730 & 15,000 & 300 & 2.4 & 0.3 \\
\hline \multirow[t]{2}{*}{ Ave. } & 7.8 & 1.9 & 450 & 12,300 & 31 & 0.3 & 0.08 \\
\hline & \multicolumn{7}{|c|}{ Culmitzsch A - Transition Zone (7 monitoring wells) } \\
\hline Min. & 7.4 & 0.1 & 145 & 5,000 & $<0.1$ & $<0.01$ & $<0.04$ \\
\hline Max. & 8.5 & 1.7 & 580 & 14,300 & 55 & 0.2 & $<0.3$ \\
\hline \multirow[t]{2}{*}{ Ave. } & 7.8 & 0.9 & 320 & 10,200 & 11 & 0.08 & 0.09 \\
\hline & \multicolumn{7}{|c|}{ Culmitzsch B - Tailings Beaches ( 2 monitoring wells) } \\
\hline Min. & 7.0 & 1.2 & 20 & 6,900 & $<0.3$ & $<0.02$ & $<0.03$ \\
\hline Max. & 9.0 & 3.5 & 225 & 8,500 & 0.4 & 0.04 & 1.2 \\
\hline \multirow[t]{2}{*}{ Ave. } & 8.0 & 2.4 & 120 & 7,700 & 0.4 & 0.03 & 0.6 \\
\hline & \multicolumn{7}{|c|}{ Culmitzsch B - Fine Tailings Zone (4 monitoring wells) } \\
\hline Min. & 7.9 & 3.5 & 20 & 4,100 & $<0.2$ & $<0.02$ & $<0.03$ \\
\hline Max. & 8.7 & 21 & 55 & 9,000 & 0.8 & $<0.02$ & 2.3 \\
\hline Ave. & 8.4 & 10 & 33 & 6,700 & 0.5 & $<0.02$ & 0.6 \\
\hline
\end{tabular}

\section{Tailings remediation}

The remediation has to ensure the safe long-term storage of the tailings reducing the additional equivalent dose to the population from all pathways to less than $1 \mathrm{mSv} /$ year (Sv = Sievert) (SSK, 1992). Requirements for waste water discharge into the receiving streams were set by the authorities of Thuringia. The remedial designs for the TPs were based on the evaluation of the technical, economical and environmental benefit following the German regulations with respect to guaranteeing geotechnical stability of the entire TP; 
minimising the volumes of soils and radioactively contaminated materials to be relocated and creating a landscape and vegetation adapted to the surrounding landscape. In situ dry-remediation in situ started with first securing measures against acute risks in 1991. The remediation of the Truenzig tailing pond shall be completed by 2013 while for Culmitzsch TP it is foreseen to last till 2022. Measures against acute risks comprised, among others, the (re-)construction of catchment systems to collect the entire seepage and runoff from the TPs and the installation of a monitoring system to track the impacts of the TPs before, during and after remediation. Before demolition of the water treatment unit in the former mill a new water treatment plant was erected in 2000/01. With respect to the overall site water management the remediation of the TPs encloses following remediation steps:

- Construction of catchment systems, where necessary, collection of seepage, supernatant water in the pond area and all contaminated runoff; water treatment and discharge of treated water into the receiving streams.

- Interim covering of air-exposed tailings surfaces and re-contouring of dams and pond areas.

- Final covering including construction of water diversion systems, access roads and vegetation.

- Construction of a surface runoff diversion system including runoff retention basins, if needed, downstream of the TP.

The discharge of treated waters is to meet the water quality requirements at the discharge point of the treatment plant, in the receiving Culmitzsch Creek and in the main river Weisse Elster. In particular the hardness $(\mathrm{CaO}+\mathrm{MgO})$ and the concentration of Uranium and of salts, like sulphate and chloride are critical for meeting the water quality requirements.

The actual remediation status of the Truenzig TP in 2011 is shown in Figure 4. Final cover placement is foreseen to be completed in 2013. The water diversion system has already partly been constructed. On the left side one can see several small ponds constructed as compensatory measures according to requirements set by the authorities under environmental law. The Culmitzsch Creek valley is located in the foreground, the Finkenbach Creek valley on the left side of Figure 4.

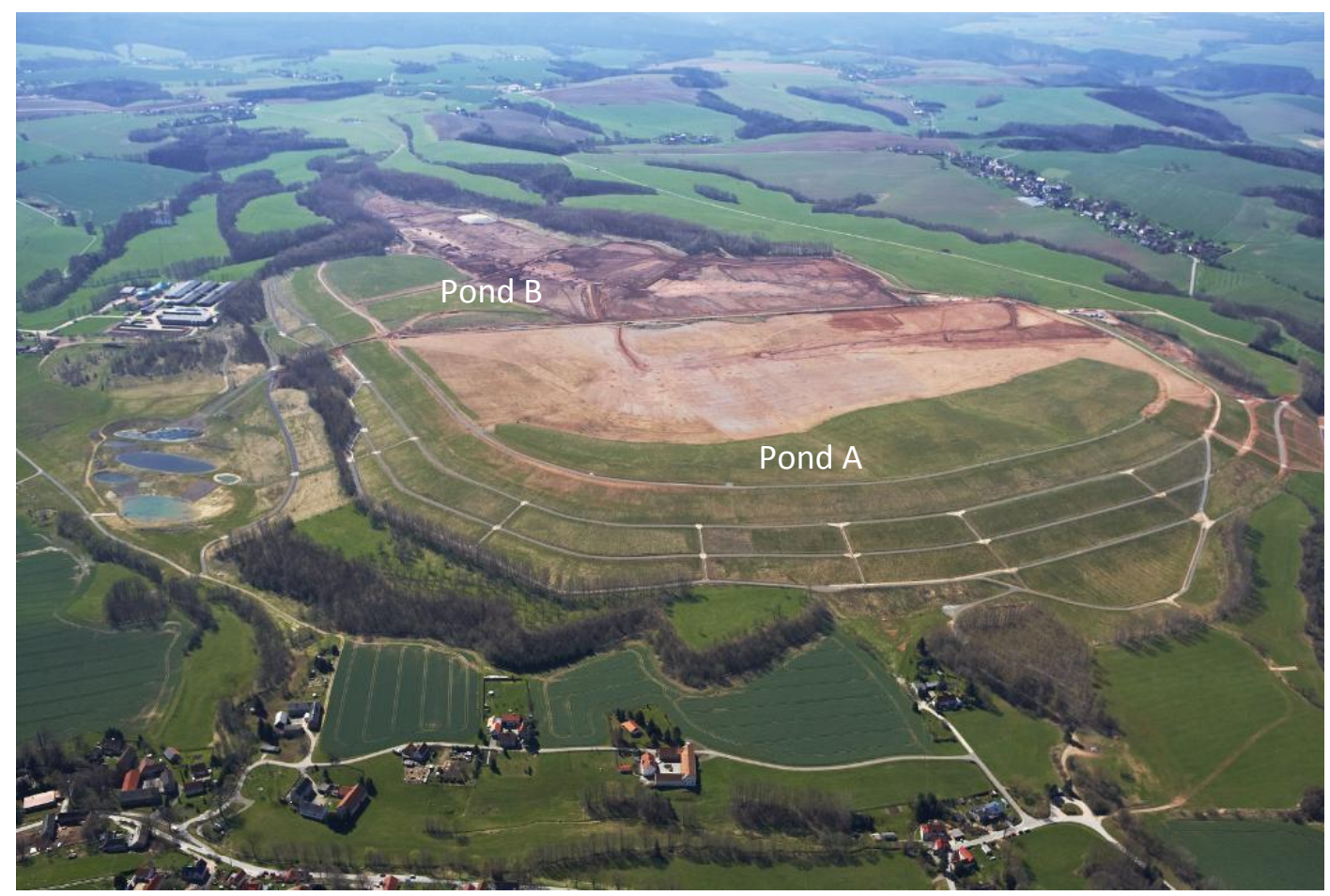

Figure 4 Truenzig TP in 2011 (aerial view from NE to SW) 
The (contaminated) groundwater flows in the underlying main aquifer layer Culmitzsch sandstone (Permian) and in fractured zones of Ordovician shales which form the deeper aquifer layer of minor importance (Figure 3). The groundwater flow is directed from the waste rock dumps in the background of pond B underneath Truenzig TP towards the Culmitzsch Creek valley located in the foreground. The Culmitzsch Creek receives contaminated groundwater flow and seepage from both Truenzig TP and Culmitzsch TP.

The final cover design for Truenzig TP was completely permitted by 2006. The final cover design depends on the underlying tailings types. On sandy tailings beach zones the final cover consists of about a $2 \mathrm{~m}$ thick storage layer including a compacted bottom lift $(0.5 \mathrm{~m})$ above a compacted interim cover of $1 \mathrm{~m}$ thickness (hydraulic conductivity $\mathrm{k}_{\mathrm{f}} \leq 5 \times 10^{-9} \mathrm{~m} / \mathrm{s}$ after construction). The final cover shall grant an average percolation rate of $\sim 80 \mathrm{~mm} /$ year. The final cover material consists of waste dump material (mixed-grained soil) from the Lokhalde waste dump located in the vicinity of the Culmitzsch TP. On fine tailings zones the functionality of the final cover shall be granted by a minimum $2.5 \mathrm{~m}$ thick layer consisting of the same mixed-grained waste dump material.

The aerial view on the Culmitzsch TP in Figure 5 shows the remedial progress achieved in 2012. The Fuchsbach Creek valley is located on the right. It will be the receiving stream for diversion of surface runoff from the major part of the entire Culmitzsch TP. On the right and in the foreground one can see the ongoing relocation of the waste rock dumps. The re-contouring of the tailings beaches of pond $A$ can be seen on the left side. On pond $A$ one can see the remaining pond water in the centre of pond $A$ and the blue coloured square of the homogenisation pond, which is part of the water management system.

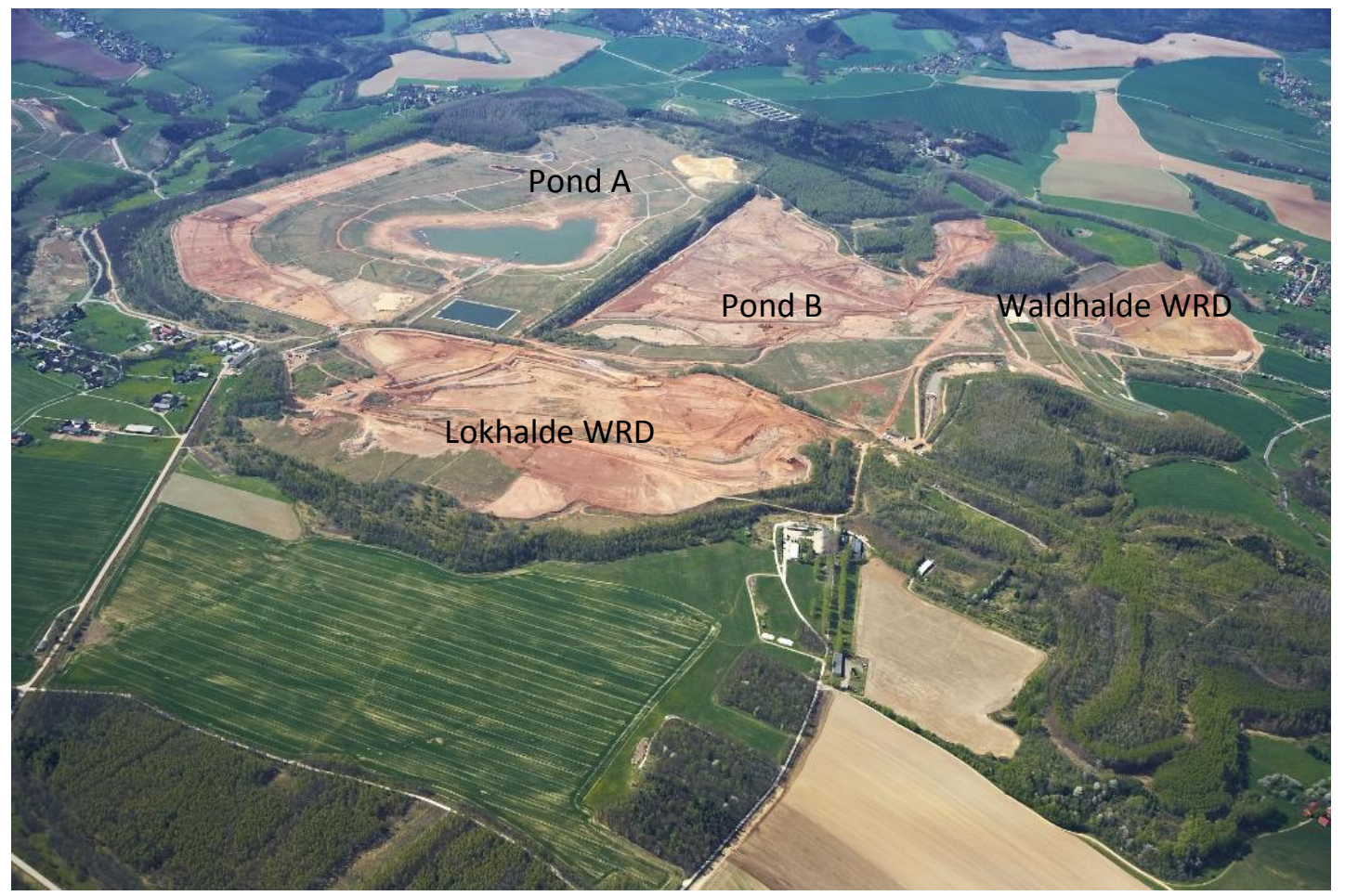

\section{Figure 5 Culmitzsch TP in 2012 (aerial view from NW to SE)}

From 1998 till 2000 the groundwater table within the tailings beaches of Culmitzsch pond A was significantly lowered by pumping resulting in a reduced seepage of groundwater into the Culmitzsch Creek valley. Due to the infiltration of surface water and a reduced pumping from the beaches because of the treatment capacity on site, the groundwater table within the tailings beaches of pond A has significantly risen since 2010. As a consequence seepage to the Culmitzsch Creek valley increased. The pumping of pore waters from the sandy beaches has proven as a very effective measure to reduce the pore water seepage from the tailings in the long term. 
The framework conception for re-contouring of the Culmitzsch TP was prepared by Wismut (Barnekow et al., 2009). It included, among other aspects, the fixing of outlet points, positions and gradients of trenches for diverting runoff and modelling of the optimum surface contour needing the minimum fill volume to build the re-contoured surface. In addition a hydrologic modelling of the runoff of the entire catchment area and hydraulic modelling of the flood levels and flooded areas along the receiving creeks was prepared and submitted to the authorities for acceptance. During the last years the re-contouring of the Culmitzsch TP was planned and permitted step-wise in construction leases. The re-contouring works have been ongoing since 2007.

The design of the entire final cover is currently prepared by our contractor C\&E Consulting and Engineering $\mathrm{GmbH}$ (Chemnitz, Germany) in collaboration with the Engineering Division of Wismut. The final cover design was determined based on conceptual site modelling of the contaminant transport from the sources (tailings, adjacent waste rock piles) to the receiving streams. Wismut plans to file the respective applications for final covering of the entire Culmitzsch TP in 2012. Beforehand the preferred final cover design will be developed and discussed with the authorities taking into account the overall water management of the entire period during and after closure mainly with regard to the long term. For evaluating the optimum final cover design with respect to the underlying tailings types and hydrological as well as hydrogeological conditions it was agreed by the authorities in early 2011, that Wismut may take credit from water management measures. These measures have to be designed together with the final cover but to be realised beforehand, to improve the water management system of all mining sites at Seelingstaedt The measures are to be evaluated using the site model of contaminant transport (Barnekow et al., 2011).

At the current state of design works we plan for a final cover on Culmitzsch TP similar to the final cover already constructed on the TP Truenzig. On the fine tailings zones the function of the final cover shall be granted by a minimum $2.5 \mathrm{~m}$ thick layer consisting of mixed-grained 'soil' from Lokhalde waste rock dump. In fact the thickness of the re-contouring layer, consisting of such compacted soils, significantly exceeds a thickness of $2.5 \mathrm{~m}$ on the major part of the fine tailings zones. Due to the very low hydraulic conductivity of the compacted waste rock material underlain by thick fine tailings the average percolation rate in the fine tailings zones was calculated to be no more than $\sim 25 \mathrm{~mm} /$ year. On the tailings beaches the final cover is currently planned to consist of a $1.5 \mathrm{~m}$ thick storage and recultivation layer above a $0.5 \mathrm{~m}$ thick drainage layer underlain by a compacted mixed-grained soil layer from Lokhalde waste rock dump (hydraulic conductivity $\mathrm{k}_{\mathrm{f}} \leq 5 \times 10^{-9} \mathrm{~m} / \mathrm{s}$ after construction). The modelling of the day-to-day water balance resulted in an average percolation rate of $\sim 50 \mathrm{~mm} /$ year.

\section{$4 \quad$ Water management - present situation}

In 2000/01 the water treatment plant Seelingstaedt was put into operation with a capacity of $300 \mathrm{~m}^{3} / \mathrm{h}$. It is located next to Culmitzsch TP treating:

- All collected surface runoff from contaminated surfaces including the mill site, Truenzig and Culmitzsch TP and the areas of the surrounding waste rock dumps Lokhalde and Waldhalde (see Figure 5).

- Collected groundwater and seepage in the Fuchsbach Creek valley and in the Culmitzsch Creek valley. The collection systems consist of pumping wells, gravel-filled drainage cuts and an areal drainage in the Culmitzsch Creek valley and of pipelines and pumping systems.

- Collected tailings pore water, in particular from pond B (since 2008).

The treatment of collected water is done by lime addition thus reducing the concentration of heavy metals such as Uranium below the discharge limits (average release limit $U=0.3 \mathrm{mg} / \mathrm{l}$, max. conc. of $U=0.5 \mathrm{mg} / \mathrm{l}$ ). The residues from water treatment are dewatered, cured and dumped into a waste disposal cells located next to the North dam on Culmitzsch partial pond B. 
Figure 6 shows the treated annual volume and the different sources of contaminated waters for the years 2007 to 2011. In 2011 about 2.2 million $\mathrm{m}^{3}$ water were treated which complies with the maximum technological capacity of the treatment plant. Due to its annual capacity the water treatment plant cannot manage the volume of surface water generated at the site in case of extreme precipitation. Presently storage capacity is available for the surplus waters in the pond A the Culmitzsch TP. In 2010 nearly all excess water from surface runoff was expelled to the Culmitzsch pond A offering the last temporarily available extensive storage volume at the site. The newly erected homogenisation pond has a capacity of about $50,000 \mathrm{~m}^{3}$ (see Figure 5). This volume was too small to buffer the varying surface runoff from precipitation from all the sites at Seelingstaedt. As a result of the high precipitation a permanent water pond developed on the fine tailings zone of pond A (see Figure 5). It existed until June 2012. This nearly stopped the interim covering progress since during the extremely wet summer season in 2010 . Up to 0.8 million $\mathrm{m}^{3}$ water were stored in pond $\mathrm{A}$. This was more than one third of the total treatment capacity at the site. A significant percentage of the treated waters are surface waters from operational areas and the TP surfaces. The remediation therefore focuses to remediate contaminated areas to reduce the amount of surface water needing treatment. The liberated treatment capacity would allow collecting and treating additional contaminated water discharges through the groundwater. As shown in Figure 7 the receiving Culmitzsch Creek is still influenced by diffusive inflow of contaminants. These outflows shall be managed in the future by reducing the infiltration into the Culmitzsch TP as well as by additional groundwater collection in the Culmitzsch valley.

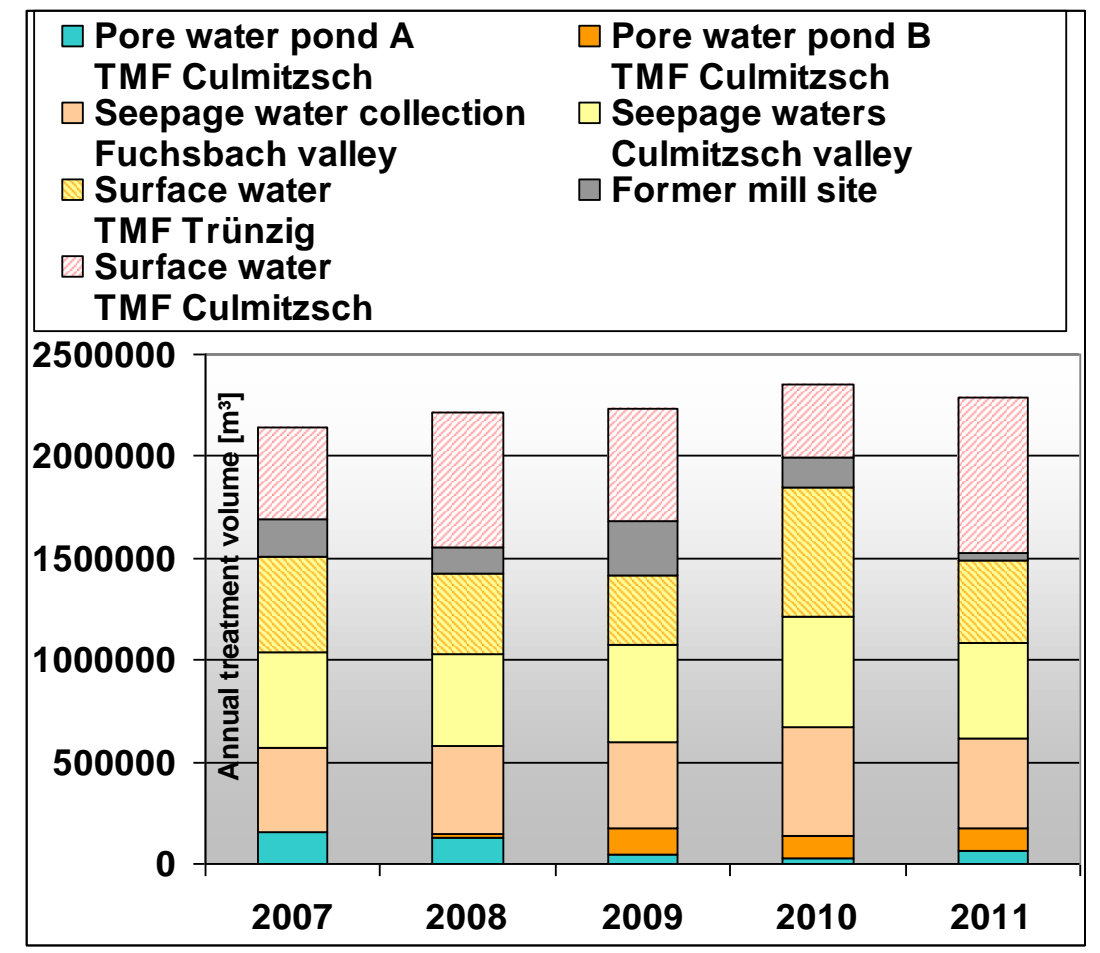

\section{Figure 6 Sources and volumes of treated waters from 2007 to 2011}

Table 2 presents the limit values to be met at the outflow point of the treatment plant and within the receiving Culmitzsch Creek. From Table 2 one can derive that the concentrations of sulphate $\left(\mathrm{SO}_{4}\right)$ is of critical importance with respect to the receiving creek. In addition the hardness $(10 \mathrm{mg} / \mathrm{l}(\mathrm{CaO}+\mathrm{MgO})$ is equal to $1^{\circ} \mathrm{dH}$ ) is of critical importance. Particularly in pond $A$ we also find high concentrations of $\mathrm{Mg}$. Thus the release of pore water from pond $A$ in the future due to the consolidation during the remediation works will critically increase the hardness value in the collected waters and subsequently also in the receiving streams. 
Table 2 Limit values for discharge of treated waters at outflow point of treatment plant

(E-307) and downstream in the receiving Culmitzsch Creek (E-369)

\begin{tabular}{|c|c|c|c|c|c|c|c|}
\hline & pH & $\begin{array}{l}U_{\text {total }} \\
\mathrm{mg} / \mathrm{l}\end{array}$ & $\begin{array}{c}\text { Hardness } \\
{ }^{\circ} \mathrm{dH}\end{array}$ & $\begin{array}{c}\mathrm{SO}_{4} \\
\mathrm{mg} / \mathrm{l}\end{array}$ & $\begin{array}{c}\mathrm{Fe} \\
\mathrm{mg} / \mathrm{l}\end{array}$ & $\begin{array}{c}\mathrm{Ni} \\
\mathrm{mg} / \mathrm{I}\end{array}$ & $\begin{array}{c}\mathrm{Zn} \\
\mathrm{mg} / \mathrm{I}\end{array}$ \\
\hline \multirow{3}{*}{$\begin{array}{l}\text { Limit } \\
\text { value }\end{array}$} & \multicolumn{7}{|c|}{ Outflow Point of Treatment Plant Seelingstaedt (E-307) } \\
\hline & 6.5 & $\begin{array}{c}0.3 \text { (annual ave) } \\
0.5 \text { (max.) }\end{array}$ & 180 & 5,000 & - & $\begin{array}{c}0.04 \text { (ave. yr) } \\
0.05 \text { (max.) }\end{array}$ & $\begin{array}{c}0.06 \text { (ave. yr) } \\
0.1 \text { (max.) }\end{array}$ \\
\hline & & \multicolumn{6}{|c|}{ Monitoring Point in Receiving Creek Culmitzsch (E-369) } \\
\hline $\begin{array}{l}\text { Limit } \\
\text { value }\end{array}$ & - & 0.5 & 180 & 5,000 & - & 0.03 & 0.05 \\
\hline
\end{tabular}

Figure 7 presents the load balance of $\mathrm{CaO}$ from the different sources for the entire Seelingstaedt area. It shows that the largest part of the load of $\mathrm{CaO}$ dominating the hardness value of the released water comes from collection of groundwater seepage from Culmitzsch pond A. This seepage is partly collected or seeps into the Culmitzsch Creek as a diffuse outflow. The hardness is also slightly increased by the water treatment scheme (compare inflow E-306 and outflow E-307 of the treatment plant).

Balance of CaO-Loads for 2011 in [t]

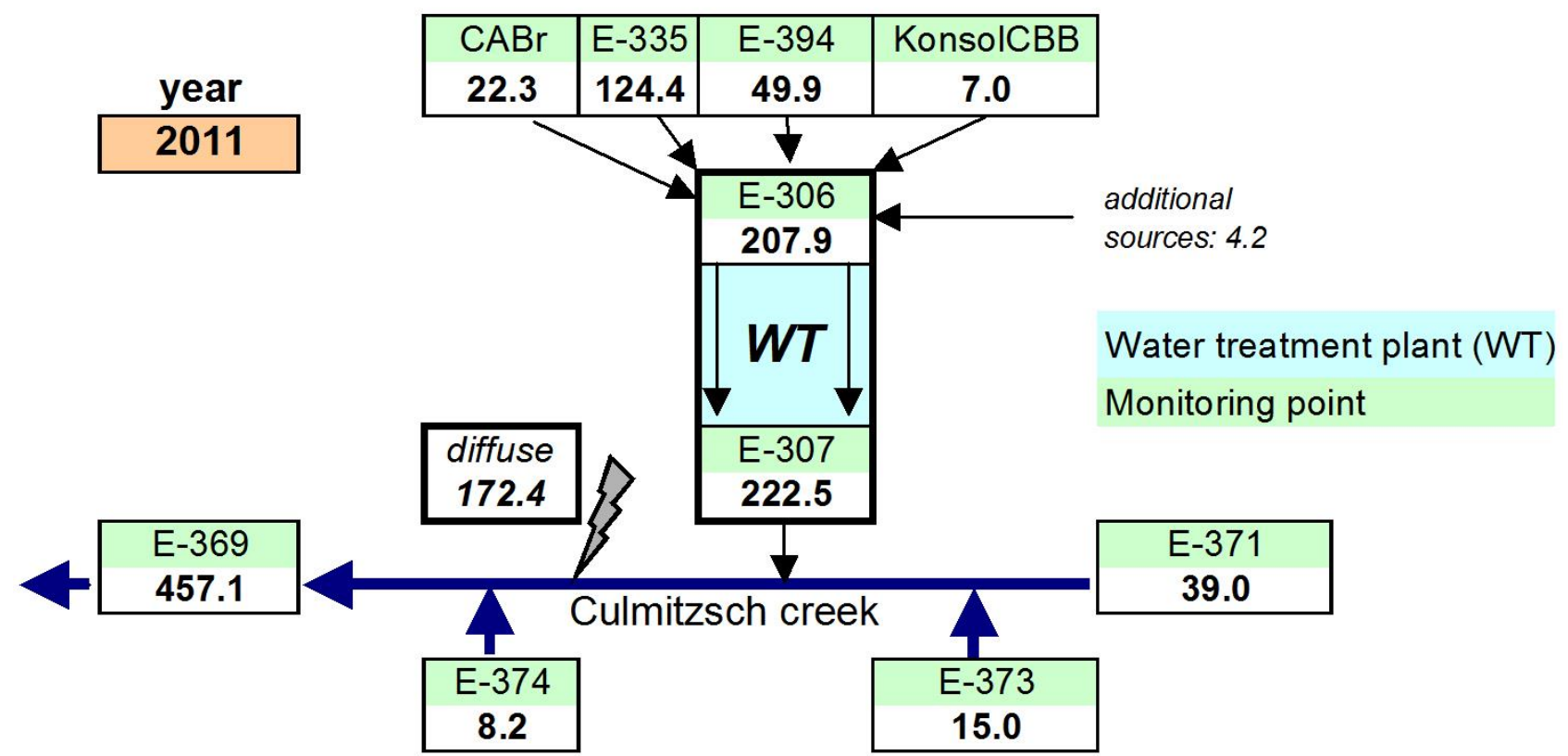

Figure 7 Load balance for release of $\mathrm{CaO}$ at the Seelingstaedt area in 2011

In addition limit values are to be met within the main river Weisse Elster (see Figure 1). Downstream of the Seelingstaedt area the water treatment plant Ronneburg discharges into the Weisse Elster river up to $750 \mathrm{~m}^{3} / \mathrm{h}$ of treated mine waters and collected effluents from the flooded Ronneburg underground mine including treated contaminated surface runoff and seepage. The most critical limit value to be met is also the hardness of the river water measured in the city of Gera downstream of both Wismut mining areas Seelingstaedt and Ronneburg. Till 2011, the limit value of hardness was fixed to be $19^{\circ} \mathrm{dH}$. This led to numerous shutdowns of the Seelingstaedt treatment plant in 2010 and 2011 to meet this limit.

In 2011, Wismut agreed with the water supplier of Saxony to control the flow of the Weisse Elster river under low flow conditions by discharge of water from three water reservoirs located upstream in Saxony. This granted a minimum flow rate of $3.5 \mathrm{~m}^{3} / \mathrm{s}$ measured at the City of Berga (Figure 1) upstream of the 
Wismut mining areas. In addition Wismut agreed with the East Thuringian water supplier to temporarily increase the flow rate in the Weisse Elster river on request with additional $0.5 \mathrm{~m}^{3} / \mathrm{s}$ by discharging from different water reservoirs located in Eastern Thuringia. In addition a software-assisted control and steering regime for the water treatment plants in Seelingstaedt and in Ronneburg was implemented taking into account the hydrological and chemical conditions in the relevant receiving streams. Having implemented this control regime as well was the management of low flow conditions Wismut applied for the increase of the limit value of the hardness in the Weisse Elster River. For this Wismut also started a new environmental biomonitoring program documenting the development of the population of protected species in different monitoring areas in the Weisse Elster River up to $70 \mathrm{~km}$ downstream of the inflow from the Wismut sites. Based on these measures the upper water authority agreed in 2011 to increase the limit value of hardness to $24^{\circ} \mathrm{dH}$ at the monitoring point located in the city of Gera (downstream of the Wismut mining areas Seelingstaedt and Ronneburg.

\section{$5 \quad$ Water management - major challenges and planned measures}

During remediation phase the major challenges for water management are to the short to mid-term:

1. Treatment and release of supernatant waters from the pond A of Culmitzsch TP in order to grant sufficient work progress on the TP areas. For this the diversion of clean surface runoff from already remediated areas such as operational areas or the Truenzig TP (see Figure 6) is of critical importance to allow optimum use of the available treatment capacity.

2. The management of released, pumped or pressed out pore waters of differing chemical composition and high concentrations in particular of sulphate, hardness or others with relevance to limit values in the receiving streams and the management of pore waters with high iron concentrations that will be pressed out due to re-contouring and covering of the fine tailings zone of Culmitzsch pond A requiring an additional water treatment of iron extraction in front of the existing water treatment plant.

After remediation phase and in the long term the major challenges are:

1. To improve the collection and groundwater catchment systems with respect to reducing the flow of contaminated groundwater to the receiving streams to a reasonably achievable amount. The design of the final cover can take credit from such measures if their efficiency can be demonstrated.

2. To divert clean surface runoff from without any treatment directly into the receiving streams granting sufficient flood prevention. For this we have to preserve the hydrologic situation of 1990 (situation without diversion of surface waters).

3. To improve the water management system with respect to efficiency and long-term costs, i.e. by installation of new collection systems and implementing new treatment technologies. Finally the treatment plant has to be adapted to the smaller annual treatment volume after the end of remediation consisting of merely seepage and groundwater.

In the following the major challenges and measures planned for are presented in more detail.

\subsection{Diversion of clean surface runoff from the remediated TP}

One fundamental requirement set by the permitting authorities of Thuringia for the conception for diversion of runoff from remediated areas is to preserve the hydrological situation given downstream in the receiving streams (Culmitzsch Creek and Fuchsbach Creek) at the status before remediation (1990) with respect to flood water flow resulting from the 100 year return event calculated based on the critical precipitation event persisting 4 hours in the respective catchment area. Therefore a hydrological model of the surface runoff was prepared for the catchment areas of the Culmitzsch and Fuchsbach creeks. The hydrological modelling was carried out for the reference state before remediation (1990) and two states 
after remediation, an interim state with only grass-vegetation on the remediated areas and the long term state with fully established vegetation such as grown-up trees. Based on the modelling results Wismut filed several applications for the subsequent release of the surface runoff from the remediated sites into the receiving streams including the construction of runoff retention ponds.

In 2012, Wismut received the planning approval for runoff diversion from the former mill site to the receiving stream. This area causes about $6 \%$ of the collected annual treatment volume in the treatment plant. We also expect to receive a preliminary approval for diversion of surface runoff from Truenzig TP A. This area accounts for approx. $15 \%$ of the total annual treatment volume. According to the current planning we assume that the diversion of surface runoff from Truenzig pond B may be implemented in 2014. The surface water discharge from this area amounts to another about $12 \%$ of the total annual treatment volume. The collection of surface runoff from Culmitzsch TP will be needed till the end of the remediation phase. This volume of surface runoff might also be useful to grant stable concentrations of the water at the inflow into the water treatment plant which will be influenced by varying releases of highly concentrated pore waters during the contouring and covering.

\subsection{Major challenges for water management due to tailings consolidation}

The major challenges from tailings consolidation for water management in the next years result from the quality of the pore water released from the tailings materials and collected in the water collection system at the site (see Table 1). The tailings pore water from the fine tailings zone of Culmitzsch pond A contains very high concentrations of iron, sulphate, chloride and Magnesia thus increasing the hardness the treated water. Currently we plan for implementing an additional water treatment step to extract iron from those pore waters. This would need the addition of hydrochloric acid thus increasing the chloride concentration of the discharged water.

The surface contour to be constructed on the pond areas was optimised based on modelling of the timedependent tailings consolidation with respect to the designed re-contoured surface and (Barnekow et al., 2009). According to the present framework conception for the Culmitzsch TP about $16 \mathrm{M} \mathrm{m}^{3}$ of mixedgrained waste dump materials will be needed for the future contouring a covering during remediation. Tailings consolidation in the fine slimes is enhanced by re-contouring combined with the use of deep vertical wick drains. On Culmitzsch pond B the interim cover was completed in 2006. Vertical wick drains of $5 \mathrm{~m}$ depth and $1.5 \mathrm{~m}$ triangular spacing were stitched in the fine tailings to achieve sufficient traffic ability by consolidation. In 2007 deep vertical wick drains were stitched through the interim cover to a depth max. $25 \mathrm{~m}$ below tailings surface in a triangular spacing of max. $6 \mathrm{~m}$. The homogenous fine tailings layer in Culmitzsch pond $B$ is up to $\sim 63 \mathrm{~m}$ thick. A drainage layer and water collection system including gravel filled drainage lines and pumping shafts was installed for collection of pressed out pore water together with surface water. Since 2008 the fine tailings have been successively under surcharge loading due to the recontouring. Figure 8 shows the predicted settlement troughs for both pond $A$ and pond $B$ of the Culmitzsch TP.

The predicted total primary settlement volume is $\sim 1.5 \mathrm{M} \mathrm{m}^{3}$ for pond $B$ and $\sim 3.5 \mathrm{M} \mathrm{m}^{3}$ for pond $A$ (Barnekow et al., 2009). Re-contouring of pond B started in 2008. From 2008 till 2012 up to $8 \mathrm{~m}$ of recontouring layer were placed on the fine tailings zone of pond $B$ resulting in measured settlements of up to $3.4 \mathrm{~m}$ of the underlying interim cover surface. Pore pressures are measured in situ depth-dependently in several profiles.

Figure 9 shows i.e. the pore pressures measured in a profile in the pond centre with time at different depths due to successive loading. One can see the pore pressure decay with time after each loading step.

Comparing the pore water concentrations with the concentrations of species in pumped water one can derive the volume of pore waters released to the surface. We calculated a volume of $\sim 240,000 \mathrm{~m}^{3}$ of pore water from November 2008 until September 2011. From the geodetic survey of ongoing settlements we calculated a settlement volume of $\sim 450,000 \mathrm{~m}^{3}$ in the same time resulting in the collection of $\sim 350,000 \mathrm{~m}^{3}$ of water pumped out of the drainage layer located above the tailings. A significant amount of the pressed 
out pore water seeped into the sandy tailings beaches. The re-contouring and final covering of Culmitzsch TP will continue till 2022. The largest part of primary settlements is predicted to develop until $\sim 2022$. The quality of the pore water of pond $B$ is characterised by high concentrations of Uranium, sulphate chloride and others. In addition we observed higher concentrations of Manganese in the pressed out pore water due dewatering of older fine tailings layers that resulted from a different processing scheme used before 1978.

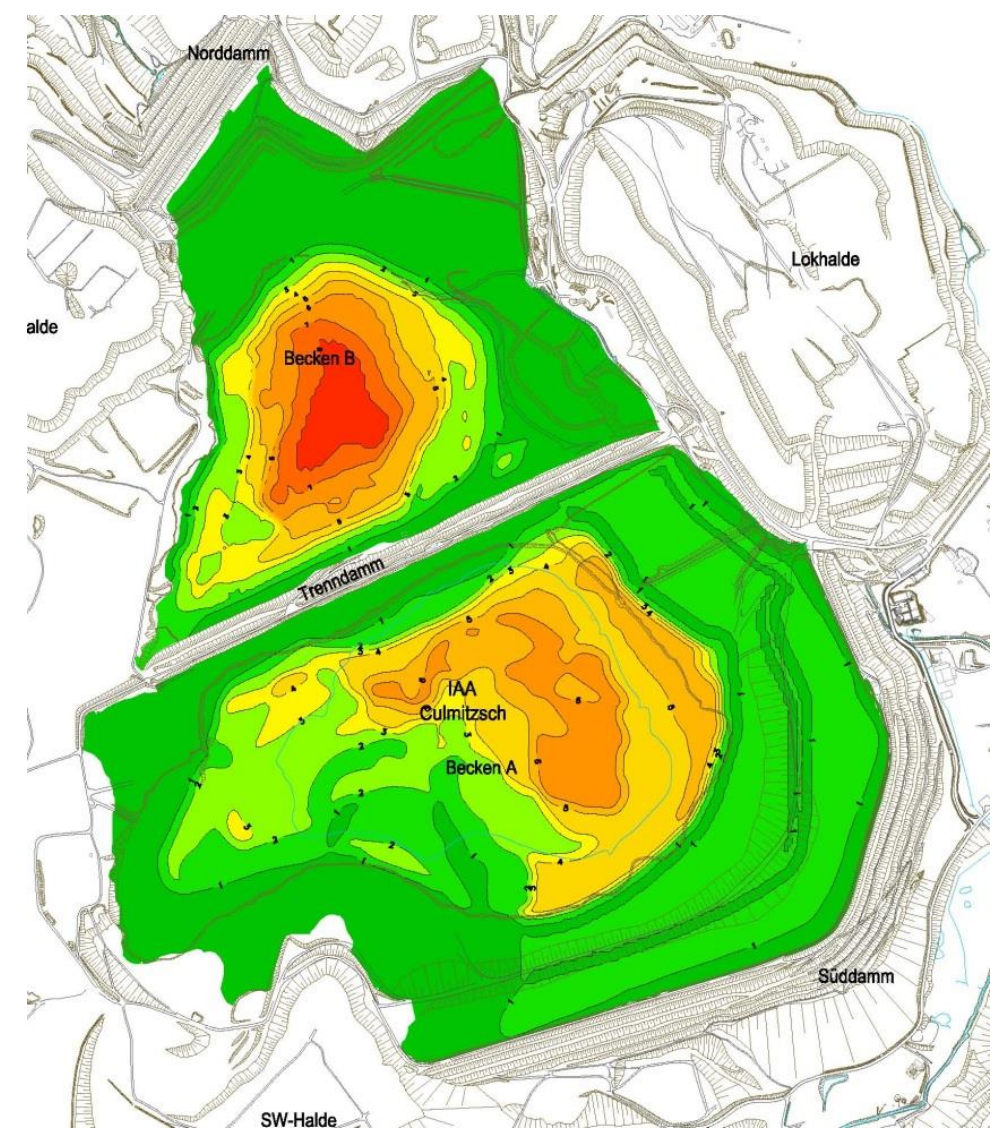

Figure 8 Predicted total settlements due to re-contouring and final covering

Culmitzsch B: In situ pore pressures measured in fine tailings (profile no. 3)

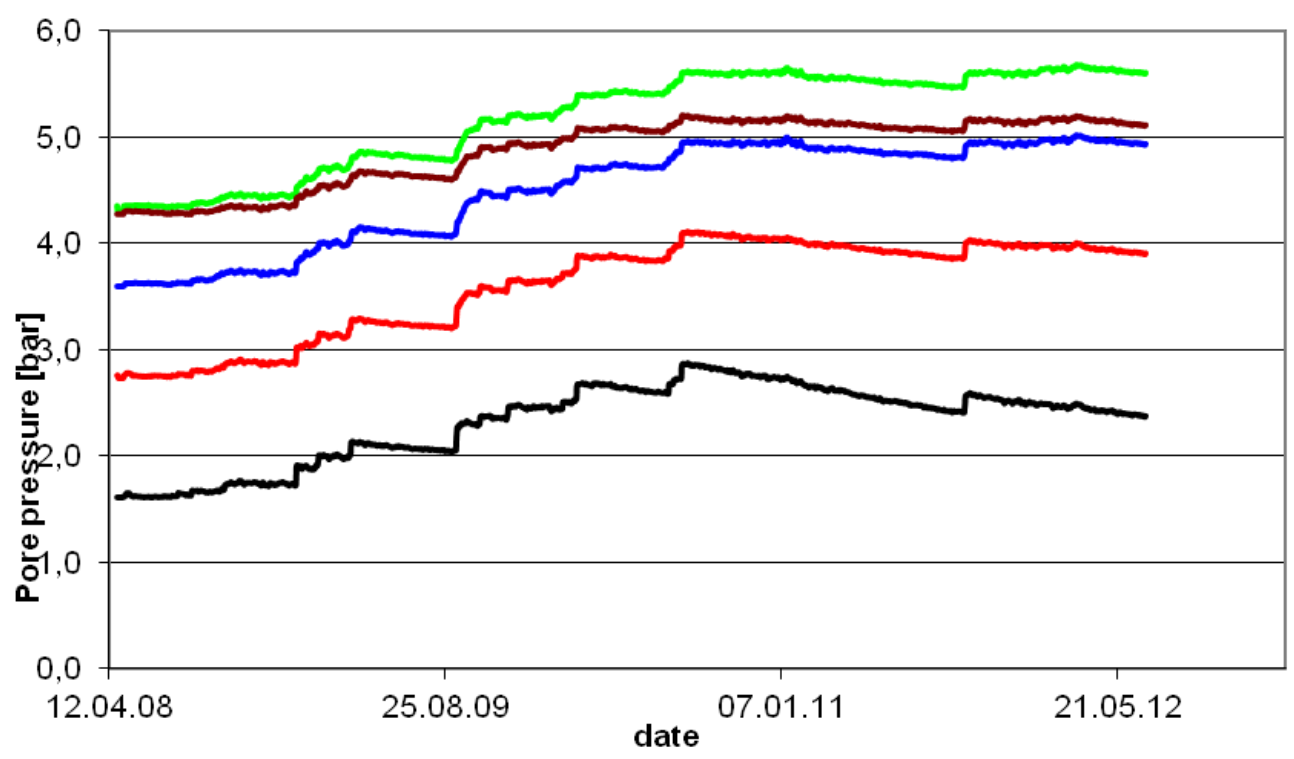

Figure 9 In situ pore pressures measured with time at different depths in the central fine tailings zone of Culmitzsch pond B 
After completion of the interim covering in 2014 the re-contouring of pond A will cause a release of about $3.5 \mathrm{M} \mathrm{m}^{3}$ of pore water. The major parts of settlements will take place until the end of remediation in 2022 in order to be able to construct the final contour and place the final cover on top of this contour. This means that from 2014 till 2022 the released pore water volume to be treated will be, in average, about $350,000 \mathrm{~m}^{3} /$ year. The quality of pore water released from the fine tailings and transition zone of pond $A$ is in particular characterised by high concentrations of sulphate, chloride, iron and a high hardness due to high concentrations of Magnesia. The sulphate concentration and hardness are critical regarding the limit value in the Culmitzsch Creek. Due to the discharge of waters with such a high hardness the limit value in the main river Weisse Elster could not be met without additional measures, in particular during dry seasons. This led to numerous shutdowns of the treatment plant in the past and would be inacceptable for the remediation progress in the future. Therefore a number of measures have already been implemented, as described above, or are planned to improve the water management during remediation (see below).

The high iron concentration measured in pore water of fine tailings and also in some areas of the transition zone in Culmitzsch pond $A$ is also of critical importance for the water treatment technology. During future re-contouring works a large amount of pore water will have to be treated. Therefore the existing water treatment plant needs an additional iron precipitation step in front of its inflow. Due to the planned addition of hydrochloric acid in this treatment step the limit value for chloride will become critical in the Culmitzsch Creek. The following chapter lists the measures foreseen to date to improve the water management.

\subsection{Planned water management measures}

The following measures are planned to further improve the water management at the site:

1. In order to increase the buffer storage capacity for collected waters Wismut applied for and received in 2011 a permit to store up to $\sim 60,000 \mathrm{~m}^{3}$ of uncontaminated surface water in a basin resulting from the excavation of contouring and cover material at the Lokhalde waste rock dump (see Figure 5 in the foreground). This allows excluding more clean surface water from treatment during wet seasons.

2. In addition Wismut applied in 2012 for a permit to store treated water from the water treatment plant in the same basin on the Lokhalde waste rock dump which is later additionally discharged when it is possible due to the geochemical conditions in the receiving stream. During dry seasons the limit values of hardness or sulphate in the receiving stream may require a shutdown of the water treatment plant. The storage of treated waters in the basin would allow continuing water treatment during dry periods. For this the necessary technical measures were implemented.

3. In order to manage the high iron concentration in the pore water from parts of the tailings of Culmitzsch pond A currently a new additional treatment step is being designed consisting of two technical parts: an iron precipitation unit and a cleaning pond. The cleaning pond shall be dimensioned with an additional volume of up to $50,000 \mathrm{~m}^{3}$ thus creating additional buffer storage volume for surface water in order to grant in the future continuously a dry surface in the centre of pond $A$. The iron precipitation is needed to grant the functionality and effectivity of the water treatment plant.

4. In 2012 Wismut applied for the permits under water law, mining law and radiation protection law to release surface water from a collection pond into the receiving stream Fuchsbach Creek without treatment. When permitted this surface water will be pumped into the receiving stream reducing the quantity of water to be treated on site.

5. Regarding future water treatment technology to the long term Wismut currently runs a pilot treatment plant (capacity $1 \mathrm{~m}^{3} / \mathrm{h}$ ) to investigate the effectivity of ion exchange treatment scheme to reduce the uranium concentration in a part of the collected waters. This would reduce the 
effort of lime treatment in the treatment plant and offer an efficient technology also for the longterm treatment at the site.

6. Hydrogeological investigations were carried out in the past and will be continued in the future for optimising the groundwater collection systems for the long term.

7. In order to reduce the seepage from pond A into the Culmitzsch Creek existing pumping wells and newly installed pumping wells shall be used to pump out pore water from the tailings beaches of pond A. Lowering the groundwater table in the tailings beaches by at least $\sim 15 \mathrm{~m}$ to $20 \mathrm{~m}$ will reduce the contaminated pore water content at least by $\sim 3 \mathrm{M} \mathrm{m}^{3}$. Thus the contaminant source will be depleted and the diffusive outflow of seepage waters into the surrounding aquifers effectively reduced. Covering ensures that this pore water volume will not be recharged again in the long-term.

\section{$6 \quad$ Conclusions and outlook}

Water management measures including collection and treatment of contaminated groundwater in the surrounding of the TP will be needed in the long term. They are required to protect the receiving streams and avoid high groundwater tables in the adjacent to the Culmitzsch TP situated village of Wolfersdorf. The modelling results of contaminant transport show that volume flow and quality of the groundwater from the TP needs a collection and treatment at least for the coming decades because:

1. None of the feasible remediation options could stop the infiltration and thereby seeping out of pore waters.

2. The stored contaminant load in the adjacent aquifers resulting from the contaminant release during the operational phase.

Lowering of the groundwater table within the tailings beaches by reducing the infiltration with the final cover will significantly lower the contaminant seepage into the Culmitzsch Creek. Nevertheless, the waters in the creek will be affected by the TP for a long time.

To date the current water management system avoids any inflow into the Fuchsbach Creek north of the Culmitzsch TP. In the future surface runoff and probably also treated water will be released into the Fuchsbach Creek because of the site morphology. Currently we start the technical planning of the surface water diversion from the Culmitzsch TP into both receiving streams the Fuchsbach Creek north and the Culmitzsch Creek south of the TP.

The further optimisation of water collection systems, treatment technology and pumping regime will be of crucial importance for reducing long-term after-care costs. Based on the understanding of the technical, hydrogeologic, hydrologic, hydraulic and geochemical regime we are able to plan for and implement step by step the needed water management measures to grant the needed remediation progress and to adapt the water management system to the long term needs.

\section{References}

Barnekow, U., Metschies, T. and Paul, M. (2009) Framework conception for the remediation of the Culmitzsch Uranium tailings pond at Wismut (Germany) with respect to contaminant release, in Proceedings Tailings and Mine Waste 2009, 1-4 November 2009, Banff, Canada.

Barnekow, U., Roscher, M. and Merkel, G. (2011) Final Covering and Diversion of Runoff from Wismut's Uranium Tailings Ponds at Seelingstaedt (Germany), Status achieved from Concepts to Realization, in Proceedings Tailings and Mine Waste 2011, 6-9 November 2011, Vancouver, Canada.

SSK (1992) Strahlenschutzkommission (German Commission on Radiation Protection SSK). Radiological Protection Principles Concerning the Safeguard, Use or Release of Contaminated Materials, Buildings, Areas or Dumps from Uranium Mining, Publication of the SSK, Vol. 23, (German/English) 198 p., 4 fig., 1 map, Bonn, 1992. 